УДК 342.95

\author{
I. С. Дрок \\ orcid.org/0000-0002-9722-2376 \\ кандидат юридичних наук, доцент, \\ науковий співробітник навчально-наукової лабораторії \\ з дослідження проблем превентивної діяльності \\ Дніпропетровського державного університету внутрішніх справ
}

\title{
ФОРМИ ВЗАЕМОДІЇ ПОЛІЦІЇ ТА МЕДИЧНИХ ЗАКЛАДІВ В УМОВАХ ЗАГОСТРЕННЯ САНІТАРНО-ЕПІДЕМІЧНОЇ СИТУАЦІЇ В УКРАЇНІ
}

Актуальність теми. Органи та підрозділи Міністерства охорони здоров'я (далі - МО3) України та Міністерства внутрішніх справ (далі - МВC) України, зокрема Національна поліція України, в умовах загострення санітарно-епідемічної ситуації тісно взаємодіють, адже від злагодженої діяльності цих двох міністерств залежить санітарне та епідемічне благополуччя населення. В умовах запровадження карантинних заходів, пов'язаних із поширенням гострої респіраторної хвороби COVID-19, спричиненої коронавірусом SARS$\mathrm{CoV}-2$, окреслене питання видається актуальним.

Постановка проблеми. Положення про Міністерство охорони здоров'я України, затверджене постановою Кабінету Міністрів України, визначає, що МОЗ України є головним органом у системі центральних органів виконавчої влади, що забезпечує формування та реалізує державну політику у сфері охорони здоров'я, зокрема й захисту населення від інфекційних хвороб, протидії ВІЛ-інфекції/СНІДу та іншим соціально небезпечним захворюванням, попередження та профілактики неінфекційних захворювань. М03 забезпечує формування та реалізує державну політику, зокрема й у сфері епідеміологічного нагляду (спостереження), імунопрофілактики, промоції здорового способу життя та запобігання факторам ризику, попередження та зниження рівня вживання тютюнових виробів і їх шкідливого впливу на здоров'я населення, безпеки харчових продуктів, регламентації факторів середовища життедіяльності населення, гігієнічної регламентації небезпечних факторів, створення національної системи крові, управління системою якості щодо безпеки крові, біологічної безпеки та біологічного захисту, боротьби зі стійкістю до протимікробних препаратів, реагування на небезпеки для здоров'я та надзвичайні стани у сфері охорони здоров'я, а також забезпечення формування державної політики у сферах санітарного та епідемічного благополуччя населення. Завдання ж Національної поліції України висвітлені у Законі України «Про Національну поліцію» і мають виконуватися за будь-яких умов. Саме співвідношення завдань та функцій медичних закладів та Національної по- ліції є пріоритетом в умовах загострення санітарно-епідемічної ситуації, адже спільних проектів не так уже й багато. Ситуація сьогодення свідчить про необхідність активізації такої взаємодії з метою підвищення ефективності діяльності вказаних органів у сферах санітарного та епідемічного благополуччя населення.

Метою статті є визначення форм взаємодії поліції та медичних закладів в умовах загострення санітарно-епідемічної ситуації в України та надання їм характеристики.

Виклад основного матеріалу. Проведений нами аналіз діяльності Національної поліції України у взаємодії з органами МОЗ України в умовах загострення санітарно-епідемічної ситуації дозволяє виокремити такі форми:

1) взаємодію під час функціонування електронного сервісу «Дій вдома» - Єдиного державного вебпорталу електронних послуг та, зокрема, інформаційної системи епідеміологічного контролю за поширенням COVID-19, що є частиною сервісу [2]. Станом на 15 червня 2020 року 40314 осіб скористалися мобільним додатком «Дій вдома» [3].

Сьогодні така взаємодія врегульована постановою Кабінету Міністрів України від 09 грудня 2020 р. № 1236 «Про встановлення карантину та запровадження обмежувальних протиепідемічних заходів із метою запобігання поширенню на території України гострої респіраторної хвороби COVID-19, спричиненої коронавірусом SARS$\mathrm{CoV}-2$ » [7]. Запропонований електронний сервіс розроблений на замовлення МОЗ України та МВС України й об'єднує функціонал обох міністерств.

Згаданою постановою Кабінету Міністрів України встановлено Порядок здійснення протиепідемічних заходів, пов'язаних із самоізоляцією, який визначає механізм здійснення протиепідемічних заходів, пов'язаних із самоізоляцією осіб, які можуть сприяти поширенню інфекційних хвороб або входять до групи ризику щодо ускладненого перебігу чи настання летальних випадків унаслідок гострої респіраторної хвороби COVID-19, спричиненої коронавірусом SARS-CoV-2.

Самоізоляція здійснюється з метою запобігання поширенню на території України COVID-19 та 
зменшення кількості хворих із тяжким перебігом COVID-19. Перелік осіб, які мають обов'язково перебувати на самоізоляції, та строк самоізоляції встановлений згаданою постановою, а також цей обов'язок додатково визначається лікарем [7].

Постановою також визначено коло осіб, які вносять до системи інформацію про визначене коло осіб, що потребують самоізоляції, як-от адміністрація Державної прикордонної служби; особисто; лікуючий лікар; працівники закладів системи екстреної медичної допомоги; працівники державних установ МОЗ України епідеміологічного профілю [7].

У разі здійснення особою самоізоляції до системи вноситься така інформація: прізвище, ім'я, по батькові особи; стать; дата народження; визначене особою місце самоізоляції; зареєстроване місце проживання особи; засоби зв'язку (номер телефону); місце роботи, заклад освіти із зазначенням адрес; наявність можливості забезпечення піклування про особу іншими особами; стан здоров'я; контактні особи; строк самоізоляції [7].

I саме одним зі способів здійснення поточного контролю особи, яка перебуває на самоізоляції, є застосування заходів контролю працівниками Національної поліції, зокрема й проведення перевірки фактичного перебування осіб за зазначеними ними адресами самоізоляції [7].

Крім того, обираючи варіант здійснення поточного контролю з використанням системи через мобільний додаток, у разі невідповідності геолокації або фотографії, відсутності зв'язку з особою через мобільний додаток, видалення, встановлення обмежень щодо передання інформації за допомогою мобільного додатка до органів Національної поліції надсилається повідомлення про випадок порушення зобов'язання щодо самоізоляції. Надсилання повідомлення є підставою для подальшого здійснення органами Національної поліції контролю за виконанням зобов'язання щодо самоізоляції [7], тобто проведення перевірки фактичного перебування осіб за зазначеними ними адресами самоізоляції.

Необхідно наголосити, що надсилання повідомлення до органів Національної поліції не може бути окремою підставою для притягнення особи до адміністративної відповідальності за порушення правил карантину, а лише вповноважує поліцейських здійснити поточний контроль [7].

Підсумовуючи, слід зазначити, що взаємодія Національної поліції України та органів МОЗ України полягає в тому, що органи МОЗ України вносять до системи "Дій удома» інформацію про осіб, які потребують самоізоляції, а Національна поліція України здійснює поточний контроль дотримання правил самоізоляції;

2) проведення інструктажів для поліцейських перед патрулюванням громадських місць про пра- вила дотримання карантину, особливості застосування протиепідемічних заходів, специфіку розповсюдження хвороби COVID-19, ознаки хвороби COVID-19 від медичних працівників, які мають достатньо професійних знань, умінь та навичок, щоб кваліфіковано роз'яснити незрозумілі питання.

Із метою запобігання поширенню на території України гострої респіраторної хвороби COVID-19, спричиненої коронавірусом SARS-CoV-2, на всій території України періодично встановлюють обмеження рішеннями Кабінету Міністрів України від 11 березня 2020 р. № 211 «Про запобігання поширенню на території України гострої респіраторної хвороби COVID-19, спричиненої коронавірусом SARS-CoV-2» [5], від 20 травня 2020 р. № 392 «Про встановлення карантину з метою запобігання поширенню на території України гострої респіраторної хвороби COVID-19, спричиненої коронавірусом SARS-CoV-2» [2], від 22 липня 2020 р. № 641 «Про встановлення карантину та запровадження посилених протиепідемічних заходів на території зі значним поширенням гострої респіраторної хвороби COVID-19, спричиненої коронавірусом SARS-CoV-2» [6], від 09 грудня 2020 р. № 1236 «Про встановлення карантину та запровадження обмежувальних протиепідемічних заходів із метою запобігання поширенню на території України гострої респіраторної хвороби COVID-19, спричиненої коронавірусом SARS-CoV-2» [7].

Відповідно до положень останнього нормативно-правового акта з метою здійснення поточного контролю на вулицях, у парках, інших громадських місцях працівники Національної поліції України проводять вибіркову перевірку документів, що посвідчують особу, підтверджують громадянство чи її спеціальний статус, а також довідок про звернення за захистом в Україні, виданих відповідно до Закону України «Про біженців та осіб, які потребують додаткового або тимчасового захисту». На електронний запит зазначених уповноважених осіб за допомогою системи надається інформація про те, чи потребує особа самоізоляції [7]. Таким чином, маючи визначене коло повноважень, із метою їх ефективного та професійного виконання поліцейські мають бути проінструктовані не тільки щодо правових аспектів їх діяльності, а й щодо тонкощів медичного характеру, зважаючи на обставини сьогодення.

Поки що такі інструктажі не проводяться перед патрулюванням поліцейських, що може вплинути на рівень ефективності несення ними служби та стан особистої безпеки поліцейських. Донесені поліцейським фахові знання медичних працівників щодо симптомів хвороби, загроз, які становить хвороба, та ефективних особистих заходів безпеки можуть уберегти чиєсь життя, дозволити правильно зреагувати у ситуаціях, пов'язаних із контактом із хворим; 
3) огляд поліцейських медичними працівниками перед патрулюванням громадських місць.

Ця форма взаємодії націлена на виключення наявності захворювань у самих поліцейських, які будуть нести службу у громадських місцях та спілкуватися з людьми.

Медичний огляд повинен бути обов'язковим. Він має включати вимірювання температури, тиску, візуальний огляд, а також проведення тесту на виявлення COVID-19 (у разі необхідності). Наша думка грунтується на статистичних даних. Так, станом на 17 грудня 2020 року (за офіційними даними МВС України) від початку пандемії вірус COVID-19 офіційно підтверджений у 26984 правоохоронців МВС України, одужало - 26049 осіб, померло від COVID-19 - 86 осіб [4];

4) залучення лікарів до онлайн-консультацій.

Розповсюдженою в період карантину стала практика онлайн-консультацій різних за фахом лікарів. Саме тому одним із напрямів взаємодії вважаємо онлайн-консультування лікарями поліцейських, які перебувають на службі з охорони публічного порядку та безпеки.

Таке консультування може стосуватися не тільки питань щодо виявлених ознак, схожих на ознаки хвороби COVID-19, а й $з$ інших медичних питань, які виникають на службі поліцейських (надання першої домедичної допомоги тощо).

Онлайн-консультування може відбуватися за допомогою телефонного зв'язку, відеозв'язку або онлайн-чатів у таких мобільних додатках, як Viber, Telegram, WatsApp тощо.

Можливо, існує потреба у створенні відповідного мобільного додатка для поліцейських та лікарів для проведення таких консультацій;

5) виклик швидкої медичної допомоги (або спеціально обладнаних медичних бригад (за можливості)) у разі виявлення в осіб ознак COVID-19. Поліцейські у разі виявлення особи таких ознак мають ужити всіх необхідних заходів для ізоляції її від оточення, застосувати засоби індивідуального захисту щодо себе, викликати швидку медичну допомогу (103 - номер гарячої лінії швидкої медичної допомоги).

$\mathrm{y}$ період карантину можуть бути організовані спеціально обладнані бригади медичної допомоги. Комплектація таких бригад унеможливлює зараження медичних працівників та ізолюе хворого від оточення за допомогою спеціальних захисних костюмів.

Висновки. Підсумовуючи викладене, маємо наголосити на важливості злагодженої взаємодії поліції та медичних закладів, особливо в умовах загострення санітарно-епідемічної ситуації. Нами виділено п'ять форм такої взаємодії, які охоплюють як внутрішню, так і зовнішню діяльність поліцейських. Окремі форми взаємодії, визначені нами, активно реалізуються на практиці та мають позитивні результати (як-от використання програми «Дій удома»). Проте деякі форми взаємодії, запропоновані у роботі, хоч і є очевидними, але потребують обов'язкового впровадження у діяльність Національної поліції України та медичних закладів (як-от проведення інструктажів медичними працівниками для поліцейських перед патрулюванням громадських місць; залучення лікарів для онлайн-консультацій поліцейських).

\section{Jimepamypa}

1. Про затвердження Положенням про Міністерство охорони здоров'я України : постанова Кабінету Міністрів України від 25 березня 2015 р. № 267. URL: https://zakon.rada.gov.ua/laws/show/267-2015$\%$ D0 $\%$ BF\#Text

2. Про встановлення карантину з метою запобігання поширенню на території України гострої респіраторної хвороби COVID-19, спричиненої коронавірусом SARS-CoV-2 : постанова Кабінету Міністрів України від 20 травня 2020 р. № 392. URL: Офіційний вісник України, 2020 р., № 43, ст. 1394, № 52, ст. 1626.

3. «Дій вдома». 40 тыс. украинцев установили приложение для контроля самоизоляции. URL: https://focus.ua/ukraine/457242-dii_vdoma_40_tys_ ukraintsev_ustanovili_prilozhenie_dlia_kontrolia_ samoizoliatsii

4. Кількість хворих правоохоронців MBC на COVID-19 за добу зросла на 315 випадків. URL: https://mvs.gov.ua/uk/press-center/news/Kilkist_ hvorih_pravoohoronciv_MVS_na_COVID_19_za_dobu_ zrosla_na_315_vipadkiv_37277.

5. Про запобігання поширенню на території України гострої респіраторної хвороби COVID-19, спричиненої коронавірусом SARS-CoV-2 : постанова Кабінету Міністрів України від 11 березня 2020 р. № 211. URL: Офіційний вісник України, 2020 р., № 23, ст. 896, № 30, ст. 1061.

6. Про встановлення карантину та запровадження посилених протиепідемічних заходів на території із значним поширенням гострої респіраторної хвороби COVID-19, спричиненої коронавірусом SARS-CoV-2 : Постанова Кабінету Міністрів України від 22 липня 2020 р. № 641. URL: Офіційний вісник України, 2020 р., № 63, ст. 2029.

7. Про встановлення карантину та запровадження обмежувальних протиепідемічних заходів з метою запобігання поширенню на території України гострої респіраторної хвороби COVID-19, спричиненої коронавірусом SARS-CoV-2 : Постанова Кабінету Міністрів України від 09 грудня 2020 р. № 1236. URL: https:// www.kmu.gov.ua/npas/pro-vstanovlennya-karantinuta-zaprovadzhennya-obmezhuvalnih-protiepidemichnihzahodiv-1236-091220. 


\section{Анотація}

Дрок I. С. Форми взаємодії поліції та медичних закладів в умовах загострення санітарно-епідемічної ситуації в У країні. - Стаття.

Метою написання статті є визначення форм взаємодії поліції та медичних закладів в умовах загострення санітарно-епідемічної ситуації в Україні та надання їм характеристики. У статті наголошено на важливості злагодженої взаємодії поліції та медичних закладів, особливо в умовах загострення санітарно-епідемічної ситуації.

Автор виділяє п'ять форм такої взаємодії, які охоплюють як внутрішню, так і зовнішню діяльність поліцейських:

- взаємодію під час функціонування електронного сервісу «Дій вдома» - Сдиного державного вебпорталу електронних послуг та, зокрема, інформаційної системи епідеміологічного контролю за поширенням COVID-19, що є частиною сервісу. Станом на 15 червня 2020 року 40314 осіб скористалися мобільним додатком «Дій вдома».

Взаємодія Національної поліції України та органів M03 України полягає в тому, що органи М03 України вносять до системи «Дій удома» інформацію про осіб, які потребують самоізоляції, а Національна поліція України здійснює поточний контроль дотримання правил самоізоляції;

- проведення медичними працівниками інструктажів для поліцейських перед патрулюванням громадських місць про правила дотримання карантину, особливості застосування протиепідемічних заходів, специфіку розповсюдження хвороби COVID-19, ознаки хвороби COVID-19;

- огляд поліцейських медичним працівником перед патрулюванням громадських місць;

- залучення лікарів до онлайн-консультацій;

- виклик швидкої медичної допомоги (або спеціально обладнаних медичних бригад (за можливості)) у разі виявлення в осіб ознак COVID-19.

Окремі форми взаємодії, визначені нами, активно реалізуються та мають позитивні результати (якот використання програми "Дій удома»). Проте деякі форми взаємодії, запропоновані в роботі, потребують обов'язкового впровадження у діяльність Національної поліції України та медичних закладів (як-от проведення інструктажів медичними працівниками для поліцейських перед патрулюванням громадських місць; залучення лікарів для онлайн-консультацій поліцейських).

Ключові слова: Національна поліція, поліцейські, медичні заклади, форми діяльності, взаємодія, санітарно-епідемічна ситуація.

\section{Summary}

Drok I.S. Forms of interaction between the police and medical institutions in the context of the aggravation of the sanitary and epidemiological situation in Ukraine. Article.

The purpose of writing this scientific article is to determine the forms of interaction between the police and medical institutions in the context of the aggravation of the sanitary and epidemiological situation in Ukraine and to give them a description. The article emphasizes the importance of coordinated cooperation between the police and medical institutions, especially in the context of the aggravation of the sanitary and epidemiological situation.

The author identifies five forms of such interaction, which cover both internal and external activities of police officers:

- Interaction during the operation of the electronic service "Home Action" - the Unified state web portal of electronic services and, in particular, the information system of epidemiological control over the spread of COVID-19, which is part of the service. As of June 15, 2020, 40,314 people used the mobile application "Home Action".

The interaction between the National Police of Ukraine and institutions of the Ministry of Health of Ukraine is that medical workers enters into the system "Home Action" information about people, who need of self-isolation, and the National Police of Ukraine monitors compliance with self-isolation rules.

- Medical staff instructs police officers before patrolling public places about the rules of quarantine, the peculiarities of anti-epidemic measures, the specifics of the spread of COVID-19, the signs of COVID-19.

- Examination of police officers by a medical worker before patrolling public places.

- Involvement of doctors in online consultations.

- Call an ambulance (or, if available, specially equipped medical teams) in case of signs of COVID-19.

Some forms of interaction identified by us are actively implemented in practice and have positive results (for example, the use of the program "Home Action"). However, some of the forms of interaction proposed in the work require the mandatory implementation of the National Police of Ukraine and medical institutions (for example, conducting briefings by medical staff for police officers before patrolling public places; involving doctors for online police consultations).

Key words: National police, police officers, medical institutions, forms of activity, interaction, sanitary and epidemic situation. 